\title{
Influence of algorithmic abstraction and mathematical knowledge on rates of dropout from Computing degree courses
}

\author{
Raphael Magalhães Hoed ${ }^{1 *} \mathbb{D}$, Marcelo Ladeira ${ }^{2}$ and Leticia Lopes Leite ${ }^{2}$
}

\begin{abstract}
This paper presents a study of rates of dropout from Brazilian degree courses, based on data provided by the National Institute for Educational Studies and Research "Anísio Teixeira" (INEP) and a case study carried out at the University of Brasilia (UnB). Dropout was calculated by tracking the status of each student between 2010 and 2014 in the eight major areas according to the classification of the Organisation for Economic Co-operation and Development (OECD), for the major area of Science, Mathematics, and Computing, and for the area of Computing. Data were analyzed in order to check for potential evidence regarding the influence on dropout of factors such as algorithmic abstraction, number of applicants per place, or the gender of students. A survey was also performed using online questionnaires for circumvented students from the courses of Bachelor of Computer Science, Degree in Computing, and Computer Engineering between 2005 and 2015. This survey revealed the influence on dropout of several factors and particularly institutional and vocational factors; it is clear that difficulties in algorithmic abstraction and mathematical knowledge influence rates of dropout from computing courses.
\end{abstract}

Keywords: Dropout, Computing, Algorithmic abstraction, Mathematical knowledge

\section{Introduction}

The number of enrolled students contributes to the budget matrix of an institution, and dropout generates a negative budget impact. "Student dropout in higher education is an international problem affecting the result of educational systems. Losses of students who begin but do not conclude their courses are social, academic, and economical wastes" [19]. In public institutions, for instance, an understanding of this phenomenon may contribute significantly to reducing wastage of resources. In private institutions, dropout and revenue loss are clearly interrelated. In Brazil, higher education in the area of Science, Mathematics, and Computing shows high dropout rates, as can be observed from the data from the National Institute for Educational Studies and Research "Anísio Teixeira" (INEP). Dropout also arises from the late diagnosis of several students at risk of circumvention, thus making it difficult to combat and reverse the problem.

\footnotetext{
* Correspondence: raphael.hoed@gmail.com

${ }^{1}$ Federal Institute of Education, Science and Technology of Northern Minas Gerais (IFNMG), Farm São Geraldo, Kilometer 06, Januária, MG CEP 39480-000, Brazil Full list of author information is available at the end of the article
}

Dropout analysis is an important step in the search for subsidies for understanding this phenomenon in order to mitigate it. The following hypotheses were therefore investigated in the present study:

i. The number of applicants per place in a course is related to student dropout.

ii. Courses in the major areas of Science, Mathematics, and Computing requiring higher levels of mathematics and algorithmic abstraction show higher dropout rates.

The general purpose of the present study was to analyze dropout from Brazilian Computing degree courses, based on data provided by INEP and a case study carried out at the University of Brasilia (UnB), in which a student was considered circumvented when "disengage[d] from the course for any reason different from degree obtainment" [6] (except in the case of death).

Dropout rates were analyzed in order to check a possible correlation with the number of applicants per place, the influence of gender, and a possible relationship 
between the requirements of algorithmic abstraction and mathematical knowledge and rates of dropout from courses in the major areas of Science, Mathematics, and Computing (and particularly from Computing degree courses). Non-parametric statistical tests were performed in these analyses since some variables did not show a normal distribution. A case study was also carried out at the UnB through the application of questionnaires to circumvented students of Computing degree courses to investigate their reasons for dropping out. Non-parametric tests, a Cronbach's alpha test, and an analysis of the content of spontaneous replies were used for data analysis.

This paper is organized as follows: The "Background" section presents the background providing the context for the development of this study. The "Methodology" section describes the methodology and the case study carried out at UnB. The "Analyses and results" section describes the analyses and results, and the "Conclusions" section presents the conclusions.

\section{Background}

In a study performed by the Special Commission for Studies of Dropout in Brazilian Public Universities [4], the concepts of course dropout (disengagement only from the course, with no disengagement from the institution), institutional dropout (disengagement from the institution in which the students were enrolled), and system dropout (disengagement from higher education) were presented. The commission recommended that the most suitable concept of dropout should be selected based on the purpose of each study.

Dropout from Computing courses is not restricted to the Brazilian education system. According to Kinnunen and Malmi [12], courses in the area of Computer Science at Helsinki University of Technology (Finland) have 500-600 entries every year, and dropout rates have ranged from 30 to $50 \%$.

According to Barroso and Falcão [3], conditions leading to school dropout can be classified into three groups: (i) economic issues, i.e., the impossibility of continuing the course due to socioeconomic reasons; (ii) vocational issues, i.e., a lack of identification with the course; and (iii) institutional issues, i.e., disengagement due to failure in the initial courses, early disabilities of previous contents, a mismatch with the methods of study, and difficulties in the relationships with institutional colleagues or members. Xenos et al. [22] identified the reasons for dropout from Computer Science degree courses at the Hellenic Open University in Patras, Greece, as follows (the student may have indicated more than one reason): professional (62.1\%), academic (46.2\%), family (17.8\%), personal $(8.9 \%)$, and health-related $(9.5 \%)$.
For courses in the major areas of Science, Mathematics, and Computing, the occurrence of students with difficulties in subjects requiring algorithmic abstraction has been reported by several authors; according to Piva and Freitas [18], "the difficulty shown by students as to algorithmic representation is due to their difficulty to extract details composing a problem situation". Regarding Computing students, Paula et al. [17] state: "Students have difficulties to build mental representations in fact abstracting a problem completely, so it is necessary to seek means to stimulate them to develop such an ability." A study carried out at the AL-AQSA University (Palestine) by Abu-Oda and El-Halees [1] involving 1290 student records between 2005 and 2011 and using data mining techniques showed that success in algorithm-related initial subjects reduces the probability of disengagement by students. Difficulties regarding algorithmic abstraction, i.e., difficulties in abstraction related to problem-solving translation in software, have therefore been identified by authors as being a particular problem for Computing students.

Several studies of the difficulties experienced by students of mathematical subjects have been published. Souza et al. [20] evaluated dropout from Brazilian degree courses over a period of 10 years, based on academic studies of this issue during this period, and observed that failures in subjects requiring mathematical knowledge are among the most frequently seen. In a study of African students of Computer Science, Gruner [8] detected a low percentage of students who wished to become researchers or scientists. This author also stated that Mathematics is becoming less fully covered in the curricula of such courses. Regarding the field of Computing, Barcelos and Silveira [2] found that "the lack of a proper domain of mathematical knowledge by students is a possible factor explaining the lack of interest and dropout in courses of this area."

The studies described in the "Analyses and results" section of the current work required dropout values to be statistically tested, with parametric and non-parametric tests as options. Regarding non-parametric tests, Maroco [13] stated that "such tests do not require a known variable (normal)." Although parametric tests have often been considered more powerful than non-parametric tests, this effect is only observed for large samples and those with equivalent size; thus, non-parametric tests are suitable for small samples and those with changeable sizes [13]. According to Vieira [21], when data normality and homoscedasticity cannot be confirmed and the sample size is reduced, non-parametric testing becomes a viable option. Since data normality is the main assumption in parametric tests, non-parametric testing must be used when normality is not detected.

In studies involving the application of questionnaires, it is necessary to check whether the items used are 
suitable for the purpose of the study, thus ensuring the reliability of the questionnaire. In the "Analyses and results" section, a Cronbach's alpha test was one of the mechanisms used to analyze the answers. According to Hora et al. [10], "alpha measures the correlation among answers in a questionnaire through their profile analysis. It refers to a mean correlation among questions." According to Maroco and Garcia-Marques [14], "the $\alpha$ index estimates how evenly items contribute with the unweighted sum of the instrument, ranging from 0 to $1 . "$

\section{Methodology}

The methodologies adopted in the present study are described below. These consisted of an analysis of national data (the "National data" section) and a case study carried out at UnB (the "Case study-UnB" section).

\section{National data}

Quantitative analyses were performed using micro-data from the Higher Education Census between 2010 and 2014, provided by INEP (2017). INEP began to make the individual data of students from 2009 available, whereas the data were provided in aggregate prior to 2009 . Changes in the methodology were made between 2009 and 2010, as observed in the technical summary of the Higher Education Census in 2010 [11]. Thus, data from 2010 were considered in the present study.

The micro-data information for each year was stored in ASCII (micro-data of 2010, 2011, and 2012) and CSV (micro-data of 2013 and 2014) files. These files contained information on students, courses, higher education institutions, professors, and places offered; files related to students and courses were used in the current work.

Before calculating dropout rates, the data were cleaned, retaining the information on the status of the students on the course (transferred, disengaged, died, attending, enrolment blocked, or graduated), the student code (unique to each student and provided by INEP), gender, the name of the course, its general area, its specific area according to the classification by the Organisation for Economic Co-operation and Development (OECD) [16], and the maintenance entity (public or private).

After cleaning, the data were transferred to a MySQL databank, from which dropout was calculated. Statistical tests were performed using SPSS Statistics version 22 software. Only non-parametric tests were used since data normality was not detected for some variables. The Spearman correlation coefficient was used to check for a possible correlation between dropout and competition. The $p$ value (significance level) was set at 0.05 , so that $p<0.05$ was considered acceptable when evaluating the significance of the obtained results. A box plot diagram was used to compare dropout rates among knowledge areas.
The number of circumvented students per year was calculated as the number of enrolments of disengaged students plus the number of enrolments of transferred students in that year, for each course. Total enrolments were obtained from the sum of the number of enrolments of active, graduated, transferred, disengaged, and deceased students per year per course. Dropout rates were obtained from the ratio between the number of circumvented students and the total number of enrolments. In this study, transfers are considered as course dropouts, even in the absence of institutional dropout.

The analyzed data comprising the dropout between 2010 and 2014 were separated into tables according to the maintenance entity (public or private institutions) and gender (male and female).

\section{Case study-UnB}

A case study was carried out at UnB to investigate the causes of student dropout from Computing courses. The total number of circumvented students between 2005 and 2015 from the degree courses offered at the Darcy Ribeiro Campus (Bachelor of Computer Science degree in Computing and Computer Engineering) was obtained from the Secretariat of Academic Records.

Several items were included in the study in order to evaluate the influence of each of them on the decision of circumvented students to disengage from the course. The prevalence of dropout-related reasons was unknown. However, a prevalence of $50 \%$ was used for sample size calculation. The following criteria were used to define the minimum number of questionnaires to be answered: $10 \%$ error margin, $90 \%$ confidence level, and 50\% prevalence. Equation 1 was used for sample size calculation:

$$
n_{0=\left[Z_{a / 2}^{2} \times p(1-p)\right] / E^{2}}
$$

where $p=50.0 \%, Z_{a / 2}=1.645$ represents the critical value corresponding to a $90 \%$ confidence level, and $E=10 \%$ represents the error margin used. After obtaining $n_{0}$, a correction was made for a finite population according to Eq. 2, in which $N$ corresponds to the total of circumvented students per course. The calculation below was made per course, thus defining the sample size for each course:

$$
n=n_{0} \times\left\{N /\left[n_{0}+(N-1)\right]\right\}
$$

Table 1 shows the number of circumvented students per course, the minimum sample size, and the number of questionnaires answered.

In order to contact students who circumvented between 2005 and 2015, their names and e-mail addresses were obtained from the Secretariat of Academic Records at UnB. Students were considered circumvented when they disengaged from the course before its conclusion, for any reason except death. Each student received an 
Table 1 Sample sizes

\begin{tabular}{llll}
\hline Course & $\begin{array}{l}\text { Circumvented } \\
\text { students }(N)\end{array}$ & $\begin{array}{l}\text { Sample } \\
\text { size }(n)\end{array}$ & $\begin{array}{l}\text { Questionnaires } \\
\text { answered }\end{array}$ \\
\hline Computer Science & 431 & 59 & 93 \\
Degree in Computing & 540 & 61 & 85 \\
Computer Engineering & 191 & 51 & 53 \\
\hline
\end{tabular}

e-mail explaining the purposes of this study and a link to the questionnaire, which was available online via Google Forms. It must be emphasized that this questionnaire did not request the student's identity.

To investigate reasons for dropout, 21 items were made available using a Likert scale questionnaire in which students were required to answer, on a scale from 0 to 5 (six levels), how strongly each item influenced their disengagement, where 0 indicated zero influence and 5 indicated a strong influence. Students could also report other reasons for their dropout if these were not mentioned in the scaled questionnaire. They could also report which subjects they considered the most difficult during the course and their reasons for choosing to attend a degree course in the field of Computing.

The Likert scale questionnaire contained items grouped into socioeconomic, vocational, and institutional issues, according to the classification proposed by Barroso and Falcão [3]. Other classifications were also used for items which did not fit into these categories, such as family, personal, health, or other issues.

The values obtained for each item of the scaled questionnaire were compared using the Kruskal-Wallis test, and the post-hoc Dunn test was used to obtain homogenous groups, with a $95 \%$ confidence interval. A non-parametric test was adopted since data normality was not detected according to the Kolmogorov-Smirnov test, in which the $p$ value was $<0.05$; thus, the null hypothesis in which the data originated from a normal distribution was rejected. Items belonging to the homogeneous group with the highest score per course were tested using Spearman's rank correlation (Spearman's rho). These tests were performed separately for each course and for all courses in general.

Other factors investigated were gender, mode of entry, period of disengagement, possible receipt of financial support, and whether the course was the first degree course of the student.

\section{Analyses and results}

This section describes the analyses, and the results of quantitative studies involving micro-data from INEP are shown (the "Analysis of micro-data from INEP" section) and the analyses and results of studies involving questionnaires applied to circumvented students of UnB (the "Analysis of questionnaires applied to circumvented students of UnB").

\section{Analysis of micro-data from INEP}

Table 2 shows the dropout rates and competition (number of applicants per place) of Brazilian courses composing the eight major knowledge areas, according to the OECD [16]. Municipal, state, and federal public institutions were considered. Private institutions included both profit-seeking and non-profit establishments. In Table 3, $N=$ number of tested samples.

Table 2 shows higher dropout rates in private institutions than in public ones, in all major areas. The competition (number of applicants per place) was higher in public institutions than in private ones.

Table 3 presents the Spearman correlation coefficient used to check for a possible statistical correlation between competition and dropout. Values were -0.485 for private institutions and -0.487 for public ones. Forty values $(N=40)$ were tested in each group, corresponding to the dropout rates and a number of applicants per place in each major area (eight in total) over 5 years (2010-2014). According to Dancey and Reidy [5], correlation coefficients can be classified as follows: $0.10-0.30$ (weak), 0.40-0.6 (moderate), and 0.70-1 (strong). A negative value indicates an inverse correlation, and the values range from -1 to 1 . Thus, competition and dropout showed a moderate inverse correlation between 2010 and 2014 in private and public institutions. The Special Commission for Studies of Dropout from Brazilian Public Universities [4] found that "low remuneration in job market decreases the search for courses, affects the training quality of students, and increases the propensity to drop out." Silva Filho et al. [19] evaluated the correlation between dropout and the number of applicants per place in general areas of knowledge in 2005 and observed that major areas showing larger numbers of applicants per place also experienced lower mean annual dropout rates than the national average (22\%). These major areas were Health and Social Welfare, Agriculture and Veterinary Medicine, Engineering, Production, and Construction. The highest dropout rate between 2001 and 2005 (services) corresponded to the lowest number of applicants per place.

In Figs. 1 and 3, the $x$-axis of the box plot diagram shows the major knowledge areas according to OECD [16]. In Figs. 2 and 4, the $x$-axis shows the grouping of the areas or courses per gender. The $y$-axis shows dropout rates. In the boxes, the lower value is represented by the lower bar, while the upper value is represented by the upper bar. The black line inside the box represents the median value. Some boxes are larger than the others, indicating a higher variation in dropout rates than in the smaller boxes. Elements outside the box (represented by a circle or an asterisk) are referred to as outliers, which correspond to unusual values in relation to the other datasets. These boxes facilitate a comparison of dropout 
Table 2 Dropout and competition in general areas of knowledge

\begin{tabular}{|c|c|c|c|c|c|c|c|c|c|c|c|}
\hline \multirow[t]{3}{*}{ Major area } & \multirow[t]{3}{*}{ Occurrence } & \multicolumn{5}{|c|}{ Private institutions } & \multicolumn{5}{|c|}{ Public institutions } \\
\hline & & \multicolumn{5}{|l|}{ Year } & \multicolumn{5}{|l|}{ Year } \\
\hline & & 2010 & 2011 & 2012 & 2013 & 2014 & 2010 & 2011 & 2012 & 2013 & 2014 \\
\hline \multirow[t]{2}{*}{ Education } & Competition & 0.55 & 0.68 & 0.80 & 0.79 & 0.70 & 4.09 & 5.88 & 6.74 & 6.93 & 6.61 \\
\hline & Dropout (\%) & 16.06 & 17.91 & 17.72 & 16.32 & 17.89 & 13.83 & 13.19 & 14.82 & 15.16 & 13.98 \\
\hline \multirow[t]{2}{*}{ Humanities and Arts } & Competition & 0.92 & 1.18 & 1.16 & 1.09 & 1.00 & 6.13 & 7.29 & 9.97 & 8.87 & 7.95 \\
\hline & Dropout (\%) & 16.07 & 18.00 & 16.76 & 17.40 & 18.29 & 14.64 & 13.46 & 12.47 & 14.91 & 12.47 \\
\hline \multirow[t]{2}{*}{ Social Sciences, Business, and Law } & Competition & 0.94 & 1.20 & 1.22 & 1.16 & 1.06 & 7.29 & 10.61 & 13.93 & 13.61 & 13.87 \\
\hline & Dropout (\%) & 15.60 & 17.44 & 17.76 & 16.76 & 17.55 & 10.43 & 10.09 & 10.35 & 10.86 & 10.59 \\
\hline \multirow[t]{2}{*}{ Sciences, Mathematics, and Computing } & Competition & 0.74 & 1.09 & 1.07 & 1.00 & 0.87 & 6.37 & 8.95 & 12.39 & 9.78 & 9.58 \\
\hline & Dropout (\%) & 18.72 & 20.22 & 19.65 & 20.22 & 20.53 & 14.97 & 14.40 & 15.46 & 15.28 & 16.01 \\
\hline \multirow[t]{2}{*}{ Engineering, Production, and Construction } & Competition & 1.33 & 1.66 & 1.85 & 1.69 & 1.35 & 8.98 & 13.42 & 16.72 & 16.32 & 15.23 \\
\hline & Dropout (\%) & 16.77 & 17.26 & 16.20 & 16.66 & 15.22 & 11.63 & 10.76 & 11.20 & 10.24 & 10.87 \\
\hline \multirow[t]{2}{*}{ Agriculture and Veterinary Medicine } & Competition & 1.11 & 1.40 & 1.69 & 1.68 & 1.05 & 7.58 & 10.47 & 12.94 & 12.02 & 12.41 \\
\hline & Dropout (\%) & 12.71 & 13.46 & 13.86 & 13.83 & 12.37 & 10.29 & 9.80 & 11.04 & 10.45 & 11.0 \\
\hline \multirow[t]{2}{*}{ Health and Social Welfare } & Competition & 1.45 & 1.82 & 2.11 & 2.05 & 1.94 & 15.28 & 19.50 & 25.91 & 25.91 & 26.8 \\
\hline & Dropout (\%) & 13.80 & 14.57 & 13.63 & 14.49 & 13.89 & 7.92 & 6.93 & 6.27 & 7.30 & 7.46 \\
\hline \multirow[t]{2}{*}{ Services } & Competition & 0.88 & 1.17 & 1.03 & 1.24 & 0.85 & 8.51 & 13.19 & 16.46 & 15.39 & 15.0 \\
\hline & Dropout (\%) & 17.12 & 20.77 & 18.97 & 18.84 & 21.50 & 13.57 & 13.07 & 14.41 & 15.44 & 16.07 \\
\hline
\end{tabular}

rates between areas, since those located in an upper position in the graph correspond to higher dropout rates in relation to those located in a lower position. In Figs. 1 and 2 , the major areas of knowledge are represented as follows: 1-Education; 2-Humanities and Arts; 3-Social Sciences, Business, and Law; 4-Science, Mathematics, and Computing; 5-Engineering, Production, and Construction; 6-Agriculture and Veterinary Medicine; 7-Health and Social Welfare; 8-Services. Box plot diagrams were generated using SPSS Statistics software version 22 .

Figure 1 was generated from the data shown in Table 2 . The highest dropout rate between 2010 and 2014 was observed for the areas of Science, Mathematics, and Computing and the area of Services, in public and private institutions. Dropout rates in these two areas were similar since their boxes are around the same height on the graph. The variability of dropout rates was higher for Services (larger box) than Science, Mathematics, and Computing. Thus, these major areas experienced higher

Table 3 Correlation test (dropout and competition)

\begin{tabular}{llll}
\hline Spearman's rho & Private institutions & Correlation coefficient & $-0.485^{* *}$ \\
& & Sig. (two-tailed) & 0.002 \\
& $N$ & 40 \\
Public institutions & Correlation coefficient & $-0.487^{* *}$ \\
& Sig. (two-tailed) & 0.001 \\
& $N$ & 40 \\
\hline
\end{tabular}

**Significant correlation at 0.01 level (two-tailed) dropout rates than others. Silva Filho et al. [19] also carried out a study of dropout from the general areas of knowledge between 2001 and 2005. The authors investigated the mean dropout from the public and private institutions during this period and observed higher values for Services (29\%) and Science, Mathematics, and Computing (28\%) than for those of other major areas and the national mean over the same period (22\%). This result was similar to that observed in the present study, in which the abovementioned major areas also showed higher dropout rates between 2010 and 2014.

Table 4 shows the dropout rates for male and female students from private institutions between 2010 and 2014 in the major areas of knowledge, while Table 5 shows the dropout from public institutions.

Figure 2 shows the box plot diagrams generated from the data in Tables 4 and 5 for private and public institutions, respectively. Each box is numbered with the identification of the major areas in Tables 4 and 5. The $x$-axis is divided into male and female students. Boxes related to male students are located in a higher position than those of the female ones, thus indicating a generally higher dropout rate for male students in the major areas of private and public institutions.

Table 6 shows the dropout rates for areas composing the major area of Science, Mathematics, and Computing, based on the classification of the OECD adopted by INEP. Thus, the area of Computing comprised the areas of Computer Science, Computer Use, and Information Processing. Degree courses were not included, since 

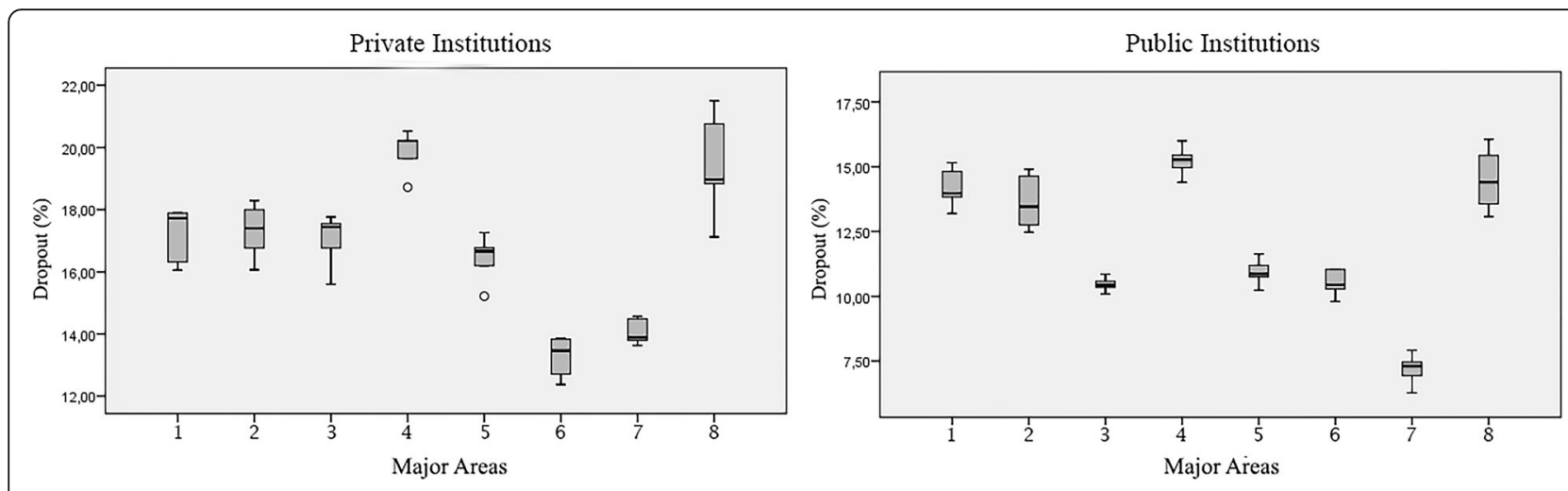

Fig. 1 Comparison of dropout rates among major knowledge areas

INEP classifies training courses of Computing professors in the major area of Education, according to the classification of the OECD [16].

Figure 3 shows the box plot diagrams generated from the data in Tables 5 and 6 in order to compare the dropout from the courses composing the major area of Science, Mathematics, and Computing. The area of Life Sciences was excluded from Fig. 3 due to the low rates of enrolment between 2010 and 2014. The area of Physical Sciences was excluded from the graph of private institutions since enrolments were only detected in 2010. For private institutions, the boxes are located in a higher position, thus indicating higher dropout rates for Physics, Mathematics, Statistics, and Computing. Since these areas require greater mathematical and algorithmic abstraction knowledge than the other courses, the hypothesis was confirmed for private institutions, thus proving hypothesis ii (the "Introduction" section). For public institutions, higher dropout rates were detected in the areas of Physics and Mathematics, which also require a high level of mathematics knowledge. Dropout rates from Computing courses were similar to those of Physical Sciences, Statistics, Chemistry, and Environmental Sciences.

Table 7 shows the dropout from Computing courses at private institutions per gender, while Table 8 shows the dropout from public institutions. The courses presented in these tables were the same as those mentioned by Nunes [15] in statistical reports of the Brazilian Computer Society (SBC). Training courses of Computing professors were considered to be degree courses, according to the nomenclature provided by the OECD. Table 7 does not show the dropout from courses in Software Engineering in 2010, 2011, and 2012, since no enrolment was detected in the micro-data from INEP over this period.

Figure 4 shows the box plot diagrams generated from the data in Tables 7 and 8. The area of Software Engineering was excluded from the diagram of private institutions since no enrolment was detected in 2010, 2011, or 2012. One the $x$-axis, the boxes are separated per gender. Boxes for both genders are located at a similar

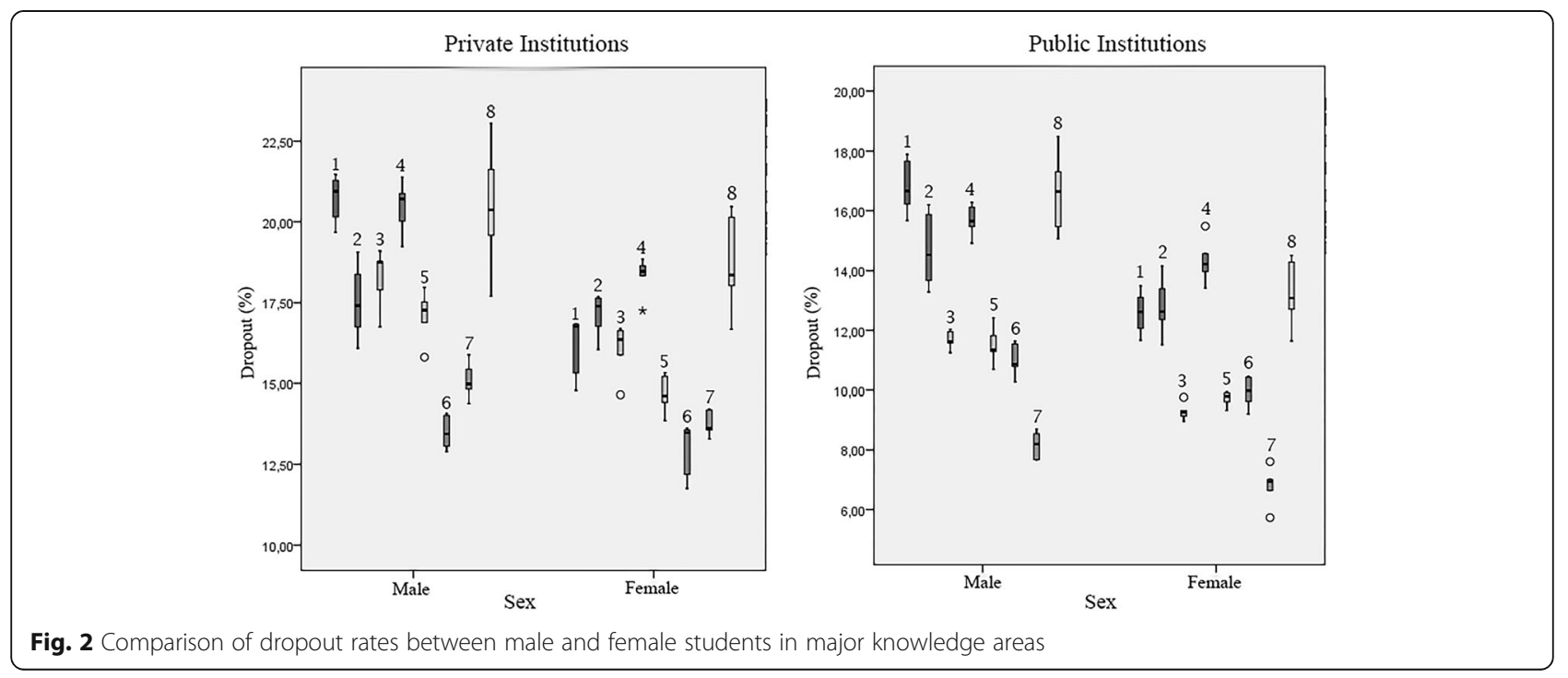


Table 4 Dropout per gender in major knowledge areas (private institutions)

\begin{tabular}{|c|c|c|c|c|c|c|c|c|c|c|}
\hline \multirow[t]{3}{*}{ Area } & \multicolumn{10}{|c|}{ Dropout (\%)_-private institutions } \\
\hline & \multicolumn{5}{|l|}{ Male } & \multicolumn{5}{|c|}{ Female } \\
\hline & 2010 & 2011 & 2012 & 2013 & 2014 & 2010 & 2011 & 2012 & 2013 & 2014 \\
\hline Education & 20.15 & 21.47 & 20.94 & 19.67 & 21.28 & 14.78 & 16.84 & 16.76 & 15.32 & 16.83 \\
\hline Humanities and Arts & 16.09 & 18.38 & 16.75 & 17.41 & 19.07 & 16.05 & 17.68 & 16.77 & 17.39 & 17.64 \\
\hline Social Sciences, Business, and Law & 16.75 & 18.77 & 19.10 & 17.90 & 18.76 & 14.65 & 16.36 & 16.69 & 15.88 & 16.63 \\
\hline Science, Mathematics, and Computing & 19.23 & 20.71 & 20.02 & 20.87 & 21.38 & 17.25 & 18.85 & 18.64 & 18.47 & 18.34 \\
\hline Engineering, Production, and Construction & 17.52 & 17.97 & 16.89 & 17.27 & 15.81 & 14.61 & 15.33 & 14.42 & 15.21 & 13.85 \\
\hline Agriculture and Veterinary Medicine & 13.06 & 13.44 & 14.07 & 14.01 & 12.89 & 12.19 & 13.48 & 13.56 & 13.61 & 11.75 \\
\hline Health and Social Welfare & 14.38 & 15.88 & 14.82 & 15.43 & 14.98 & 13.62 & 14.18 & 13.28 & 14.21 & 13.57 \\
\hline Services & 17.70 & 21.62 & 20.37 & 19.58 & 23.05 & 16.67 & 20.14 & 18.03 & 18.36 & 20.47 \\
\hline
\end{tabular}

height, which indicates no significant differences in dropout per gender, with some minor variations, e.g., in the course of Degree in Computing in private institutions, which shows a higher dropout of male students. Figure 4 does not indicate a relationship between dropout from Computing courses and the gender of students.

\section{Analysis of questionnaires applied to circumvented students of UnB}

This section presents an analysis of the answers from circumvented students on the degree courses of Computer Science, Computer Engineering, and Degree in Computing, offered by UnB. Table 9 shows the sample demographics.

As mentioned in the "Case study-UnB" section, the questionnaire applied to circumvented students of UnB to identify their reasons for dropout consisted of 21 items. The respondents were asked to indicate how far each item influenced their decision to circumvent the course. Each item ranged from 0 to 5 (where 0 indicated zero influence and 5 indicated a strong influence on dropout). Items were organized according to Table 10, which contains their classification and description, and the position of the question in the sequence in which they were answered by the respondent. Items were chosen according to those fitting into the reasons for student dropout presented by Barroso and Falcão [3] (socioeconomic, vocational, and institutional issues); options added were family/personal/ health reasons and other issues.

Cronbach's alpha test was used to check for correlations between the classifications used in the present study. Table 11 shows the values of Cronbach's alpha for each classification. A total of 231 cases were tested, corresponding to the number of respondents from Computer Science (93 cases), Degree in Computing (85 cases), and Computer Engineering (53 cases).

According to Hair et al. [9] regarding the values of Cronbach's alpha, 0.60 represents the lower limit of acceptability for exploratory studies, while 0.70 is the limit for other types of study. The higher the value, the higher the reliability of the indicator. The present study is considered to be exploratory. According to Godoy [7], a study is exploratory if it aims to improve the knowledge of the target object. Table 11 shows that all classifications except "Other issues" had values of Cronbach's alpha higher than 0.60 . Since the classification of "Other issues" includes several items not fitting into the other classifications, it is understandable that its value is low. However, the more specific classifications had suitable

Table 5 Dropout per gender in major knowledge areas (public institutions)

\begin{tabular}{|c|c|c|c|c|c|c|c|c|c|c|}
\hline \multirow[t]{3}{*}{ Detailed area } & \multicolumn{10}{|c|}{ Dropout (\%)—public institutions } \\
\hline & \multicolumn{5}{|l|}{ Male } & \multicolumn{5}{|c|}{ Female } \\
\hline & 2010 & 2011 & 2012 & 2013 & 2014 & 2010 & 2011 & 2012 & 2013 & 2014 \\
\hline Education & 16.66 & 15.67 & 17.66 & 17.89 & 16.22 & 12.07 & 11.67 & 13.10 & 13.49 & 12.62 \\
\hline Humanities and Arts & 16.20 & 14.53 & 13.68 & 15.87 & 13.28 & 13.39 & 12.63 & 11.52 & 14.15 & 12.36 \\
\hline Social Sciences, Business, and Law & 11.58 & 11.25 & 11.61 & 12.03 & 11.95 & 9.26 & 8.96 & 9.14 & 9.76 & 9.32 \\
\hline Science, Mathematics, and Computing & 15.47 & 14.91 & 16.11 & 15.65 & 16.28 & 13.97 & 13.42 & 14.22 & 14.57 & 15.48 \\
\hline Engineering, Production, and Construction & 12.42 & 11.29 & 11.82 & 10.69 & 11.34 & 9.79 & 9.61 & 9.90 & 9.32 & 9.94 \\
\hline Agriculture and Veterinary Medicine & 10.79 & 10.27 & 11.54 & 10.86 & 11.63 & 9.63 & 9.20 & 10.45 & 9.98 & 10.42 \\
\hline Health and Social Welfare & 8.70 & 7.68 & 7.67 & 8.20 & 8.54 & 7.61 & 6.64 & 5.73 & 6.94 & 7.01 \\
\hline Services & 15.06 & 15.47 & 16.64 & 17.30 & 18.49 & 12.71 & 11.64 & 13.08 & 14.29 & 14.51 \\
\hline
\end{tabular}


Table 6 Dropout rates from courses in the major areas of Science, Mathematics, and Computing

\begin{tabular}{|c|c|c|c|c|c|c|c|c|c|c|}
\hline \multirow[t]{3}{*}{ Area } & \multicolumn{10}{|c|}{ Dropout (\%) } \\
\hline & \multicolumn{5}{|c|}{ Private institutions } & \multicolumn{5}{|c|}{ Public institutions } \\
\hline & 2010 & 2011 & 2012 & 2013 & 2014 & 2010 & 2011 & 2012 & 2013 & 2014 \\
\hline Life Sciences (general courses) & - & - & - & - & - & - & 20.73 & 29.89 & 22.75 & - \\
\hline Biology and Biochemistry & 16.38 & 18.76 & 18.25 & 17.18 & 16.74 & 13.86 & 12.72 & 11.59 & 11.81 & 14.52 \\
\hline Environmental Sciences & 10.50 & 19.07 & 12.93 & 10.77 & 5.67 & 10.18 & 14.91 & 18.07 & 17.59 & 19.18 \\
\hline Physical Sciences (general courses) & 11.02 & - & - & - & - & 19.03 & 15.17 & 16.09 & 13.88 & 16.15 \\
\hline Physics & 21.26 & 35.52 & 18.91 & 17.56 & 18.05 & 21.16 & 25.97 & 20.65 & 24.09 & 21.74 \\
\hline Chemistry & 13.44 & 15.08 & 14.59 & 18.14 & 14.26 & 15.24 & 12.65 & 14.64 & 16.21 & 14.08 \\
\hline Soil Sciences & 12.31 & 17.61 & 20.02 & 18.46 & 13.86 & 10.75 & 11.15 & 11.47 & 12.54 & 13.13 \\
\hline Mathematics & 5.60 & 29.01 & 26.32 & 22.06 & 19.55 & 28.39 & 27.49 & 24.23 & 26.90 & 26.53 \\
\hline Statistics & 19.81 & 22.20 & 20.62 & 17.37 & 18.68 & 14.87 & 14.45 & 17.51 & 18.39 & 18.19 \\
\hline Computing & 19.42 & 20.74 & 20.16 & 21.10 & 21.89 & 14.23 & 13.87 & 16.18 & 15.12 & 15.88 \\
\hline
\end{tabular}

values for an exploratory study, thus indicating that, in the general analysis of all respondents, reasons for dropout can be classified according to the system presented in Table 10.

Table 12 shows the results of the Kruskal-Wallis test for subsets of homogenous items for the course of Computer Science. A total of 1953 values were tested (93 answers in each item, multiplied by 21 items). The chi-square value was 335.607, with 20 degrees of freedom and $p$ value $<$ 0.05 , thus indicating statistically significant differences between the items. The largest homogeneous subset observed in Table 12 is subset 9, composed of items 3, 6, 12, $1,11,4,5,9,14$, and 7; of these, item 1 is classified as socioeconomic, while the others are classified as vocational or institutional. This shows that vocational, institutional, and socioeconomic issues were predominant among the reasons for dropout from the course of Bachelor of Computer Science at UnB.
Table 13 shows the results of the Spearman correlation test between item 9 (difficulties in mathematics-related subjects) and the other items in the largest homogenous subset. A significant correlation was detected between item 9 and items 7 (criteria for evaluation of students were unsuitable or very rigid), 11 (lack of information on subjects covered by the course), 12 (unsuitable physical infrastructure within the institution), and 14 (difficulties in understanding lecturers). According to Dancey and Reidy [5], the correlation coefficient can be classified as follows: $0.10-0.30$ (weak), 0.40-0.6 (moderate), and $0.70-1$ (strong). Based on this classification, a moderate correlation was detected for items 7,11 , and 14 (all of which are classified as institutional), thus indicating that mathematics-related difficulties were correlated to institutional factors, according to the respondents.

Table 14 shows the results of the Kruskal-Wallis test for the subsets of homogenous items for the course of

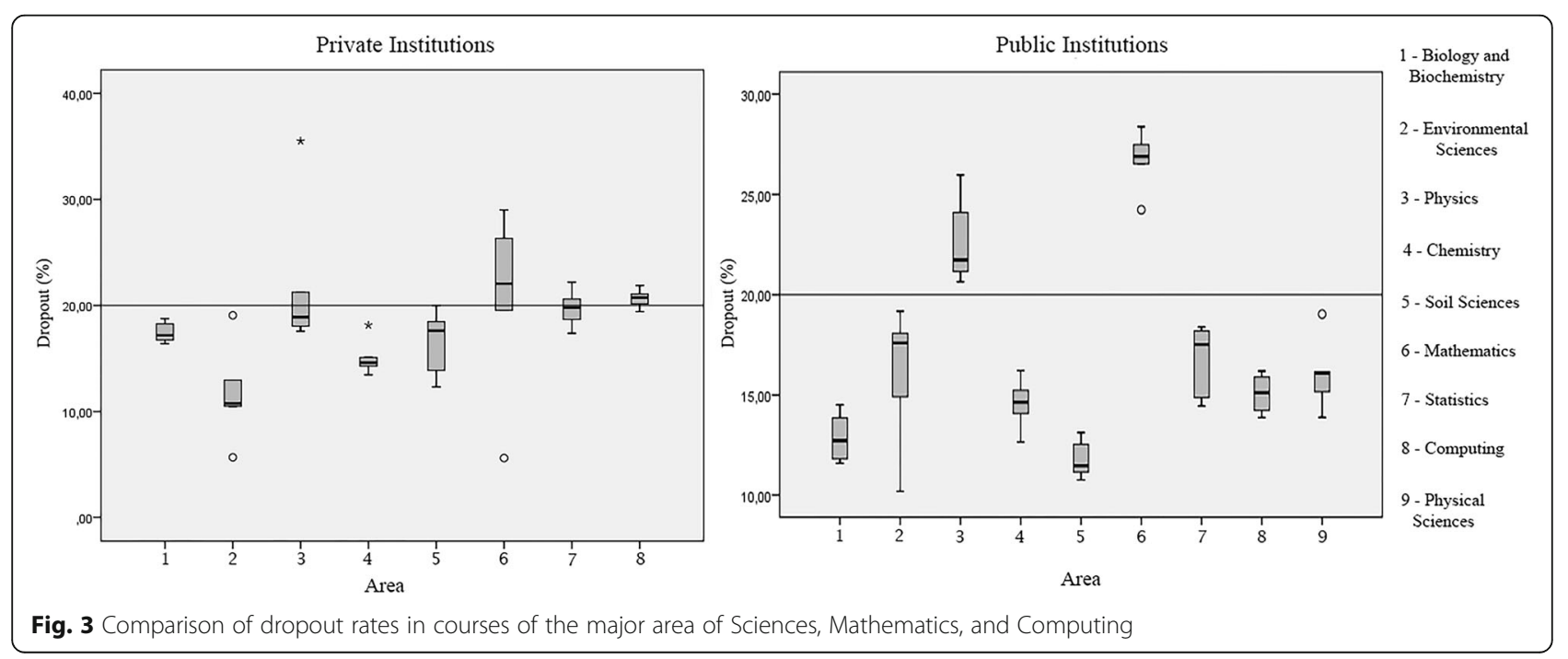


Table 7 Dropout from Computing courses-male and female students (private institutions)

\begin{tabular}{|c|c|c|c|c|c|c|c|c|c|c|}
\hline \multirow[t]{3}{*}{ Course } & \multicolumn{10}{|c|}{ Dropout (\%)—private institutions } \\
\hline & \multicolumn{5}{|l|}{ Male } & \multicolumn{5}{|c|}{ Female } \\
\hline & 2010 & 2011 & 2012 & 2013 & 2014 & 2010 & 2011 & 2012 & 2013 & 2014 \\
\hline Computer Science & 19.72 & 20.77 & 21.52 & 21.15 & 19.10 & 19.57 & 19.61 & 22.65 & 21.50 & 18.73 \\
\hline Computer Engineering & 20.81 & 23.01 & 20.33 & 19.74 & 19.54 & 22.71 & 23.00 & 20.11 & 19.32 & 19.32 \\
\hline Software Engineering & - & - & - & 13.64 & 4.40 & - & - & - & 41.67 & 4.35 \\
\hline Information Systems & 17.81 & 18.68 & 17.72 & 19.31 & 19.37 & 17.95 & 17.60 & 18.11 & 19.03 & 19.73 \\
\hline Degree in Computing & 22.12 & 23.99 & 14.25 & 23.12 & 28.13 & 19.76 & 20.99 & 13.87 & 20.34 & 23.15 \\
\hline Technology & 20.63 & 22.48 & 21.10 & 22.27 & 24.21 & 20.83 & 23.26 & 22.56 & 23.35 & 26.17 \\
\hline
\end{tabular}

Degree in Computing. A total of 1785 values were tested ( 85 answers for each item multiplied by 21 items). The chi-square value was 278.360 , with 20 degrees of freedom and $p$ value $<0.05$, thus indicating statistically significant differences between the items. Item 1 showed the highest score. It should be emphasized that the Degree in Computing is offered at $\mathrm{UnB}$ in the evenings, allowing students to work during the day. Thus, difficulty in reconciling work and study was a very important factor affecting the dropout of students. Since item 1 is alone in subset 10, subset 9 was also considered for analysis. Subset 9 was composed of items 4, 12, 11, 5, 14, 9, and 7 , which were classified as vocational or institutional. This indicates that vocational, institutional, and socioeconomic (as described by item 1 ) issues were predominant among the reasons for dropout from the course of Degree in Computing at UnB, as for the course of Bachelor of Computer Science.

Table 15 shows the results of the Spearman correlation test between item 9 (difficulties in mathematics-related subjects) and other items in the largest homogenous subset. Significant correlation was detected between item 9 and items 4 (lack of affinity with the course), 5 (dedication to other studies), 7 (criteria for the evaluation of students were unsuitable or very rigid), 11 (lack of information on subjects covered by the course), 12 (unsuitable physical infrastructure within the institution), and 14 (difficulties in understanding lecturers).
According to the classification proposed by Dancey and Reidy [5], this correlation can be classified as moderate for items 7 and 11 and strong for item 14 (all of which are classified as institutional), as observed for the course in Bachelor of Computer Science, thus indicating that mathematics-related difficulties were correlated with institutional factors, according to the respondents.

Table 16 shows the results of the Kruskal-Wallis test for the subsets of homogenous items in the course of Computer Engineering. A total of 1113 values were tested (53 answers for each item multiplied by 21 items). The chi-square value was 292.670, with 20 degrees of freedom and $p$ value $<0.05$, thus indicating statistically significant differences between the items. The largest homogenous subset observed in Table 16 was subset 9 , composed of items $8,13,7,3,11,14,6$, and 4 , all of which are classified as vocational or institutional. This indicates that vocational and institutional issues were predominant among the reasons for dropout from the course in Computer Engineering at UnB.

Table 17 shows the results of the Spearman correlation test between item 8 (difficulties in subjects related to programming and algorithms) and the other items in the largest homogenous subset. A significant correlation was detected between item 8 and items 3 (change to a course in different area), 4 (lack of affinity with the course), and 6 (lack of identification with professionals in this area). Based on the classification proposed by Dancey and

Table 8 Dropout from Computing courses - male and female students (public institutions)

\begin{tabular}{|c|c|c|c|c|c|c|c|c|c|c|}
\hline \multirow[t]{3}{*}{ Course } & \multicolumn{10}{|c|}{ Dropout (\%)_-public institutions } \\
\hline & \multicolumn{5}{|l|}{ Male } & \multicolumn{5}{|c|}{ Female } \\
\hline & 2010 & 2011 & 2012 & 2013 & 2014 & 2010 & 2011 & 2012 & 2013 & 2014 \\
\hline Computer Science & 13.51 & 13.06 & 13.90 & 13.47 & 14.01 & 13.37 & 15.12 & 14.73 & 14.87 & 15.93 \\
\hline Computer Engineering & 11.44 & 10.41 & 11.95 & 11.02 & 11.44 & 5.96 & 10.63 & 12.45 & 10.15 & 11.70 \\
\hline Software Engineering & 9.22 & 10.05 & 13.53 & 9.17 & 13.45 & 15.63 & 10.71 & 10.53 & 8.51 & 14.75 \\
\hline Information Systems & 16.35 & 13.51 & 13.88 & 16.34 & 15.12 & 16.49 & 12.82 & 13.26 & 17.09 & 17.08 \\
\hline Degree in Computing & 13.48 & 17.70 & 17.98 & 20.71 & 18.19 & 10.05 & 18.43 & 17.75 & 17.23 & 16.68 \\
\hline Technology & 13.75 & 14.46 & 17.42 & 14.76 & 16.68 & 15.81 & 16.09 & 19.10 & 17.00 & 18.13 \\
\hline
\end{tabular}



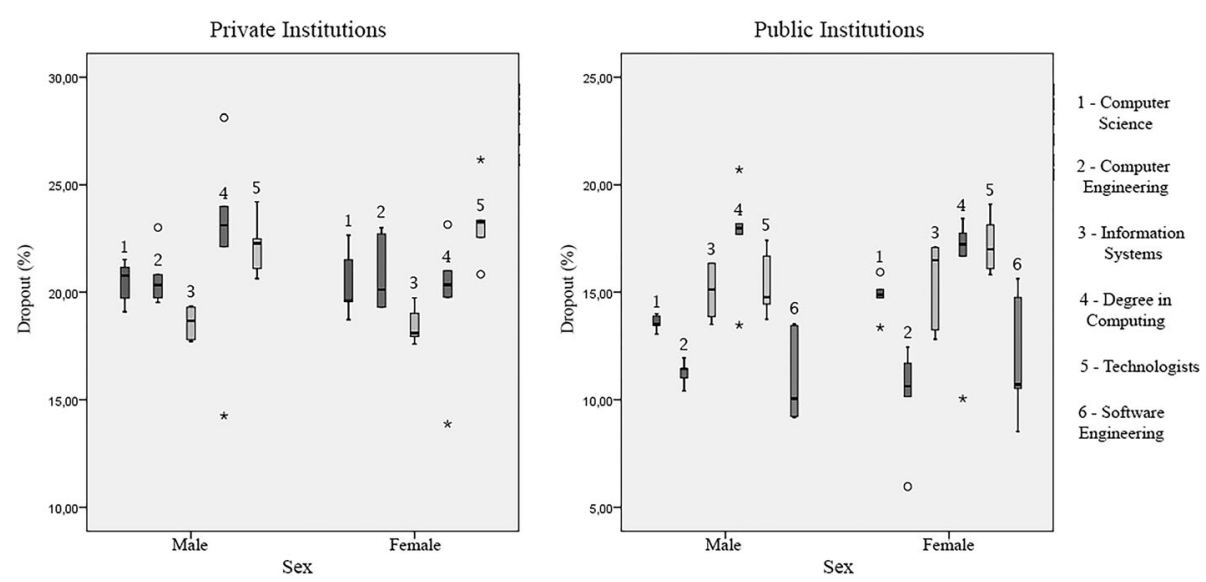

Fig. 4 Comparison of dropout in Computing courses

Reidy [5], this correlation can be classified as moderate for item 3 (vocational), thus indicating that the difficulty with algorithms was correlated with vocational issues, according to the respondents.

Table 18 shows the results of the Kruskal-Wallis test for the subsets of homogenous items considering all results for the three evaluated courses. A total of 4851 values were tested (231 answers for each item multiplied by 21 items). The chi-square value was 787.352, with 20 degrees of freedom and $p$ value $<0.05$, thus indicating

Table 9 Sample demographics

\begin{tabular}{|c|c|c|c|}
\hline \multicolumn{4}{|c|}{ Respondents per course (\%) } \\
\hline & $\begin{array}{l}\text { Computer } \\
\text { Science }\end{array}$ & $\begin{array}{l}\text { Computer } \\
\text { Engineering }\end{array}$ & $\begin{array}{l}\text { Degree in } \\
\text { Computing }\end{array}$ \\
\hline \multicolumn{4}{|l|}{ Gender } \\
\hline Female & 7.53 & 13.21 & 8.24 \\
\hline Male & 92.47 & 86.79 & 91.76 \\
\hline \multicolumn{4}{|l|}{ Shares } \\
\hline Shareholders & 16.13 & 18.87 & 9.41 \\
\hline Non-shareholders & 83.87 & 81.13 & 90.59 \\
\hline \multicolumn{4}{|l|}{ Entry } \\
\hline ENEM/SISU ${ }^{1}$ & 5.38 & 5.66 & 12.94 \\
\hline Entrance examination & 70.97 & 79.25 & 67.06 \\
\hline $\mathrm{PAS}^{2}$ & 16.13 & 15.09 & 16.47 \\
\hline Others & 7.53 & 0.00 & 3.53 \\
\hline \multicolumn{4}{|l|}{ Financial support } \\
\hline Yes & 5.38 & 15.09 & 8.24 \\
\hline No & 94.62 & 84.91 & 91.76 \\
\hline \multicolumn{4}{|l|}{ First higher education } \\
\hline Yes & 73.12 & 86.79 & 63.53 \\
\hline No & 26.88 & 13.21 & 36.47 \\
\hline
\end{tabular}

ENEM/SISU National Secondary Education Examination/Unified Selection System, PAS Program of Serial Evaluation
Table 10 Reasons for dropout from Computing courses

\begin{tabular}{|c|c|c|}
\hline Classification & $\begin{array}{l}\text { Question } \\
\text { number }\end{array}$ & Item \\
\hline \multirow{3}{*}{$\begin{array}{l}\text { Socioeconomic } \\
\text { issues }\end{array}$} & 1 & Impossibility of conciliating work and study \\
\hline & 2 & Financial difficulties \\
\hline & 15 & Non-receipt of financial support \\
\hline \multirow{4}{*}{$\begin{array}{l}\text { Vocational } \\
\text { issues }\end{array}$} & 3 & Change to a course in different field \\
\hline & 4 & Lack of affinity with the course \\
\hline & 5 & Dedication to other studies \\
\hline & 6 & $\begin{array}{l}\text { Lack of identification with professionals in } \\
\text { this area }\end{array}$ \\
\hline \multirow[t]{8}{*}{$\begin{array}{l}\text { Institutional } \\
\text { issues }\end{array}$} & 7 & $\begin{array}{l}\text { Criteria for the evaluation of students were } \\
\text { unsuitable or very rigid }\end{array}$ \\
\hline & 9 & Difficulties in mathematics-related subjects \\
\hline & 8 & $\begin{array}{l}\text { Difficulties in subjects related to programming } \\
\text { and algorithms }\end{array}$ \\
\hline & 10 & Difficulties in other subjects \\
\hline & 11 & $\begin{array}{l}\text { Lack of information on subjects covered } \\
\text { by the course }\end{array}$ \\
\hline & 12 & $\begin{array}{l}\text { Unsuitable physical infrastructure within } \\
\text { the institution }\end{array}$ \\
\hline & 13 & Relationship difficulties with professors/staff \\
\hline & 14 & Difficulties in understanding lecturers \\
\hline \multirow{4}{*}{$\begin{array}{l}\text { Family/personal/ } \\
\text { health issues }\end{array}$} & 17 & Family distance \\
\hline & 18 & Affective disorders \\
\hline & 20 & Relationship difficulties with colleagues \\
\hline & 21 & Health problems (yours or a relative's) \\
\hline \multirow[t]{2}{*}{ Other issues } & 16 & $\begin{array}{l}\text { Transfer to another institution, while } \\
\text { continuing the same course }\end{array}$ \\
\hline & 19 & Change of municipality \\
\hline
\end{tabular}


Table 11 Cronbach's alpha for each classification evaluated in the present study

\begin{tabular}{lll}
\hline Classification & Cronbach's alpha & No. of items \\
\hline Socioeconomic & 0.636 & 3 \\
Vocational & 0.717 & 4 \\
Institutional & 0.800 & 8 \\
Family/personal/health & 0.644 & 4 \\
Other issues & 0.457 & 2 \\
\hline
\end{tabular}

statistically significant differences between the items. The largest homogenous subset observed in Table 18 was subset 7 , composed of items $6,1,5,4,11,9,14$, and 7 , which are classified as vocational $(4,5,6)$, institutional $(7,9,11,14)$, and socioeconomic (item 1).

Table 19 shows the results of the Spearman correlation test between item 9 (difficulties in mathematics-related subjects) and other items in the largest homogenous subset. Significant correlation was detected between item 9 and items 4 (lack of affinity with the course), 5 (dedication to other studies), 6 (lack of identification with professionals in this area), 7 (criteria for the evaluation of students were unsuitable or very rigid), 11 (lack of information on subjects covered by the course), and 14 (difficulty in understanding lecturers). Based on the classification proposed by Dancey and Reidy [5], this correlation can be classified as moderate for the institutional items 7,11 , and 14, thus indicating that the difficulties in mathematics are correlated with institutional factors, according to the respondents.

Circumvented students also had the option to add other relevant reasons for their disengagement from the three courses at UnB, in the case where the elements described in the scale questionnaire did not reflect all their reasons for dropout. Of the 93 respondents for Computer Science, 26 added reasons for dropout; of the 85 respondents for the Degree in Computing, 27 added reasons for dropout; and of the 53 respondents for Computer Engineering, 20 added reasons for dropout. These answers were classified as institutional, vocational,

Table 12 Kruskal-Wallis test (Computer Science)

\begin{tabular}{|c|c|c|c|c|c|c|c|c|c|}
\hline \multicolumn{10}{|c|}{ Mean rank and homogenous subsets } \\
\hline \multirow[t]{2}{*}{ Item $^{1}$} & \multicolumn{9}{|l|}{ Subset } \\
\hline & 1 & 2 & 3 & 4 & 5 & 6 & 7 & 8 & 9 \\
\hline 3 & 622.586 & & & & & & & & \\
\hline 17 & 632.72 & & & & & & & & \\
\hline 15 & 696.758 & 696.758 & & & & & & & \\
\hline 16 & 710.823 & 710.823 & 710.823 & & & & & & \\
\hline 2 & & 790.887 & 790.887 & 790.887 & & & & & \\
\hline 20 & & 818.048 & 818.048 & 818.048 & 818.048 & & & & \\
\hline 21 & & 819.301 & 819.301 & 819.301 & 819.301 & & & & \\
\hline 18 & & & 869.726 & 869.726 & 869.726 & & & & \\
\hline 10 & & & & 912.613 & 912.613 & 912.613 & & & \\
\hline 8 & & & & 937.242 & 937.242 & 937.242 & 937.242 & & \\
\hline 13 & & & & & 984.285 & 984.285 & 984.285 & 984.285 & \\
\hline 3 & & & & & & 1093.33 & 1093.33 & 1093.33 & 1093.33 \\
\hline 6 & & & & & & & 1104.43 & 1104.43 & 1104.43 \\
\hline 12 & & & & & & & 1113.15 & 1113.15 & 1113.15 \\
\hline 1 & & & & & & & 1115.05 & 1115.05 & 1115.05 \\
\hline 11 & & & & & & & & 1165.84 & 1165.84 \\
\hline 4 & & & & & & & & 1174.51 & 1174.51 \\
\hline 5 & & & & & & & & 1215.00 & 1215.00 \\
\hline 9 & & & & & & & & 1225.69 & 1225.69 \\
\hline 14 & & & & & & & & & 1253.26 \\
\hline 7 & & & & & & & & & 1261.75 \\
\hline Chi-square value & 7.599 & 9.011 & 7.836 & 8.886 & 10.661 & 6.689 & 10.969 & 13.817 & 9.247 \\
\hline Sig. (two-tailed test) & 0.055 & 0.061 & 0.098 & 0.114 & 0.059 & 0.082 & 0.052 & 0.087 & 0.415 \\
\hline
\end{tabular}

Homogenous subsets are based on asymptotic significances. The significance level was 0.05

${ }^{1}$ Each cell indicates the mean sample position for the variable item 
Table 13 Correlation test-item 9 (Computer Science)

\begin{tabular}{|c|c|c|c|c|c|c|c|c|c|c|c|}
\hline & & & 11 & 13 & 14 & 15 & 16 & 17 & 111 & 112 & 114 \\
\hline \multirow[t]{3}{*}{ Spearman's rho } & Item 9 & Correlation coefficient & 0.029 & 0.019 & 0.151 & -0.009 & 0.054 & $0.544^{*}$ & $0.504^{*}$ & $0.272^{*}$ & $0.527^{*}$ \\
\hline & & Sig. (two-tailed) & 0.783 & 0.854 & 0.149 & 0.928 & 0.606 & 0.000 & 0.000 & 0.008 & 0.000 \\
\hline & & $N$ & 93 & 93 & 93 & 93 & 93 & 93 & 93 & 93 & 93 \\
\hline
\end{tabular}

*Significant correlation at 0.01 (two-tailed)

socioeconomic, and other issues, and institutional issues were widely cited, as shown in Table 20 . Widely cited issues included an outdated curriculum and an unsuitable choice of courses, lack of suitability of the course with respect to the job market, lack of educational background, and successive failures.

When giving reasons for choosing a Computing course, more than $50 \%$ of students from each course attributed their motivation as being mainly due to affinity, curiosity, and an interest in computers or the field of computing.
According to the answers from the respondents, most of these students disengaged from the course during the first four periods: $61.28 \%$ for Computer Science, $58.82 \%$ for Degree in Computing, and $64.14 \%$ for Computer Engineering.

\section{Conclusions}

The analysis of micro-data from INEP between 2010 and 2014 based on non-parametric tests gave the following results: the number of applicants per place was inversely proportional to dropout; rates of dropout were different for the major knowledge areas, with the highest values

Table 14 Kruskal-Wallis test (Degree in Computing)

\begin{tabular}{|c|c|c|c|c|c|c|c|c|c|c|}
\hline \multicolumn{11}{|c|}{ Mean rank and homogenous subsets } \\
\hline \multirow[t]{2}{*}{ Item $^{1}$} & \multicolumn{10}{|l|}{ Subset } \\
\hline & 1 & 2 & 3 & 4 & 5 & 6 & 7 & 8 & 9 & 10 \\
\hline 17 & 627.524 & & & & & & & & & \\
\hline 19 & 652.465 & & & & & & & & & \\
\hline 20 & 662.147 & & & & & & & & & \\
\hline 16 & 667.253 & & & & & & & & & \\
\hline 15 & 669.7 & & & & & & & & & \\
\hline 21 & 701.071 & 701.071 & & & & & & & & \\
\hline 18 & 779.1 & 779.1 & 779.1 & & & & & & & \\
\hline 2 & & 828.641 & 828.641 & 828.641 & & & & & & \\
\hline 10 & & 848 & 848 & 848 & 848 & & & & & \\
\hline 6 & & & 889.006 & 889.006 & 889.006 & 889.006 & & & & \\
\hline 8 & & & 891.641 & 891.641 & 891.641 & 891.641 & & & & \\
\hline 3 & & & 896.941 & 896.941 & 896.941 & 896.941 & 896.941 & & & \\
\hline 13 & & & 921.859 & 921.859 & 921.859 & 921.859 & 921.859 & 921.859 & & \\
\hline 4 & & & 975.835 & 975.835 & 975.835 & 975.835 & 975.835 & 975.835 & 975.835 & \\
\hline 12 & & & & 994.847 & 994.847 & 994.847 & 994.847 & 994.847 & 994.847 & \\
\hline 11 & & & & & 1041.87 & 1041.87 & 1041.87 & 1041.87 & 1041.87 & \\
\hline 5 & & & & & & 1055.62 & 1055.62 & 1055.62 & 1055.62 & \\
\hline 14 & & & & & & & 1098.22 & 1098.22 & 1098.22 & \\
\hline 9 & & & & & & & & 1116.47 & 1116.47 & \\
\hline 7 & & & & & & & & & 1159.87 & \\
\hline 1 & & & & & & & & & & 1274.92 \\
\hline Chi-square value & 9.958 & 7.623 & 10.692 & 10.077 & 12.778 & 12.491 & 10.928 & 11.304 & 10.897 & 2 \\
\hline Sig. (two-tailed test) & 0.126 & 0.054 & 0.153 & 0.184 & 0.078 & 0.086 & 0.091 & 0.079 & 0.092 & \\
\hline
\end{tabular}


Table 15 Correlation test-item 9 (Degree in Computing)

\begin{tabular}{|c|c|c|c|c|c|c|c|c|c|}
\hline & & & 11 & 14 & 15 & 17 & 111 & 112 & 114 \\
\hline \multirow[t]{3}{*}{ Spearman's rho } & Item 9 & Correlation coefficient & -0.049 & $0.399^{* *}$ & $0.239^{*}$ & $0.562^{* *}$ & $0.533^{* *}$ & $0.223^{*}$ & $0.716^{* *}$ \\
\hline & & Sig. (two-tailed) & 0.656 & 0.000 & 0.028 & 0.000 & 0.000 & 0.040 & 0.000 \\
\hline & & $N$ & 85 & 85 & 85 & 85 & 85 & 85 & 85 \\
\hline
\end{tabular}

*Significant correlation at 0.05 (two-tailed)

**Significant correlation at 0.01 (two-tailed)

in the major areas of Services and Science, Mathematics, and Computing; for courses in the major area of Science, Mathematics, and Computing, those requiring a greater knowledge of mathematics and algorithmic abstraction had higher dropout rates in private institutions. On average over all the major areas, dropout was higher for male students than for females. For Computing, dropout rates were similar for both genders.

Based on the case study carried out at UnB, institutional, vocational, and socioeconomic issues were the reasons most cited as contributing significantly to dropout from the courses of Computer Science and Degree in Computing. For Computer Engineering, institutional and vocational factors were also often cited. For the courses of Computer Science and Degree in Computing, difficulty in mathematics-related subjects was one of the institutional factors most often cited. This factor was directly correlated with institutional factors (criteria for the evaluation of students were unsuitable or very rigid, lack of information subjects covered by the course, difficulty in understanding lecturers), thus indicating that in addition to a difficulty in mathematics representing a relevant factor for dropout, students see a relationship between their difficulties in these subjects and

Table 16 Kruskal-Wallis test (Computer Engineering)

\begin{tabular}{|c|c|c|c|c|c|c|c|c|c|}
\hline \multicolumn{10}{|c|}{ Mean rank and homogenous subsets } \\
\hline \multirow[t]{2}{*}{ Item $^{1}$} & \multicolumn{9}{|l|}{ Subset } \\
\hline & 1 & 2 & 3 & 4 & 5 & 6 & 7 & 8 & 9 \\
\hline 17 & 317.43 & & & & & & & & \\
\hline 19 & 349.17 & 349.17 & & & & & & & \\
\hline 15 & 361.32 & 361.32 & & & & & & & \\
\hline 16 & 371.66 & 371.66 & & & & & & & \\
\hline 2 & 388.76 & 388.76 & & & & & & & \\
\hline 21 & 409.90 & 409.90 & 409.90 & & & & & & \\
\hline 18 & 428.38 & 428.38 & 428.38 & & & & & & \\
\hline 1 & & 440.53 & 440.53 & 440.53 & & & & & \\
\hline 20 & & & 522.20 & 522.20 & 522.20 & & & & \\
\hline 10 & & & & 536.20 & 536.20 & & & & \\
\hline 9 & & & & & 608.79 & 608.79 & & & \\
\hline 12 & & & & & 614.11 & 614.11 & 614.11 & & \\
\hline 5 & & & & & 630.68 & 630.68 & 630.68 & 630.68 & \\
\hline 8 & & & & & 638.31 & 638.31 & 638.31 & 638.31 & 638.31 \\
\hline 13 & & & & & 644.93 & 644.93 & 644.93 & 644.93 & 644.93 \\
\hline 7 & & & & & & 711.60 & 711.60 & 711.60 & 711.60 \\
\hline 3 & & & & & & 714.02 & 714.02 & 714.02 & 714.02 \\
\hline 11 & & & & & & 732.93 & 732.93 & 732.93 & 732.93 \\
\hline 14 & & & & & & & 741.77 & 741.77 & 741.77 \\
\hline 6 & & & & & & & & 765.51 & 765.51 \\
\hline 4 & & & & & & & & & 768.80 \\
\hline Chi-square value & 11.559 & 9.197 & 7.276 & 4.666 & 10.545 & 13.51 & 13.77 & 12.74 & 12.008 \\
\hline Sig. (two-tailed test) & 0.073 & 0.163 & 0.064 & 0.097 & 0.104 & 0.061 & 0.055 & 0.079 & 0.1 \\
\hline
\end{tabular}

Homogenous subsets are based on asymptotic significances. The significance level was 0.05

${ }^{1}$ Each cell indicates the mean sample position for the variable item 
Table 17 Correlation test-item 8 (Computer Engineering)

\begin{tabular}{|c|c|c|c|c|c|c|c|c|c|}
\hline & & & 13 & 14 & 16 & 17 & 111 & 113 & 114 \\
\hline \multirow[t]{3}{*}{ Spearman's rho } & Item 8 & Correlation coefficient & $0.408^{* *}$ & $0.321^{*}$ & $0.292^{*}$ & 0.255 & 0.210 & -0.021 & 0.015 \\
\hline & & Sig. (two-tailed) & 0.003 & 0.021 & 0.038 & 0.071 & 0.139 & 0.882 & 0.918 \\
\hline & & $N$ & 53 & 53 & 53 & 53 & 53 & 53 & 53 \\
\hline
\end{tabular}

*Significant correlation at 0.05 (two-tailed)

**Significant correlation at 0.01 (two-tailed)

institutional issues. For the course of Computer Engineering, difficulty in subjects related to programming and algorithms was one of the most often cited institutional factors. This factor was significantly and moderately correlated with the vocational item 3 (change to a course in a different area). It must be noted that when giving their reasons for choosing a Computing degree course, most of the circumvented students attributed their main reasons as affinity, curiosity, and an interest in computers and in the field of computing. However, vocational aspects were widely cited by respondents as the reasons for dropout. Regarding this divergence, it should be emphasized that the item "Lack of information on subjects covered by the course: I expected to find different subjects and contents from those offered" was one of the most often cited in the questionnaires answered by students from all courses, thus indicating that many students had no idea of what the course covered, although they had already had some contact with computing. Family/personal/health and other issues were not cited as the strongest reasons for dropout from the evaluated courses.

Although the present study cannot reach the overall conclusions for such a complex and vast subject, it does

Table 18 Kruskal-Wallis test (all courses)

\begin{tabular}{|c|c|c|c|c|c|c|c|}
\hline \multicolumn{8}{|c|}{ Mean rank and homogenous subsets } \\
\hline \multirow[t]{2}{*}{ Item $^{1}$} & \multicolumn{7}{|l|}{ Subset } \\
\hline & 1 & 2 & 3 & 4 & 5 & 6 & 7 \\
\hline 17 & 1576.63 & & & & & & \\
\hline 19 & 1622.71 & & & & & & \\
\hline 15 & 1723.75 & & & & & & \\
\hline 16 & 1725.93 & & & & & & \\
\hline 21 & & 1926.15 & & & & & \\
\hline 20 & & 2003.16 & & & & & \\
\hline 2 & & 2005.52 & & & & & \\
\hline 18 & & 2075.13 & & & & & \\
\hline 10 & & & 2299.44 & & & & \\
\hline 8 & & & 2469.48 & 2469.48 & & & \\
\hline 13 & & & 2549.75 & 2549.75 & 2549.75 & & \\
\hline 3 & & & & 2705.96 & 2705.96 & 2705.96 & \\
\hline 12 & & & & 2721.13 & 2721.13 & 2721.13 & \\
\hline 6 & & & & & 2762.74 & 2762.74 & 2762.74 \\
\hline 1 & & & & & 2827.49 & 2827.49 & 2827.49 \\
\hline 5 & & & & & 2896.88 & 2896.88 & 2896.88 \\
\hline 4 & & & & & & 2919.81 & 2919.81 \\
\hline 11 & & & & & & 2938.96 & 2938.96 \\
\hline 9 & & & & & & 2950.67 & 2950.67 \\
\hline 14 & & & & & & 3090.41 & 3090.41 \\
\hline 7 & & & & & & & 3132.24 \\
\hline Chi-square value & 7.027 & 2.586 & 5.466 & 6.876 & 10.008 & 15.318 & 11.554 \\
\hline Sig. (two-tailed test) & 0.071 & 0.46 & 0.065 & 0.076 & 0.075 & 0.053 & 0.116 \\
\hline
\end{tabular}

Homogenous subsets are based on asymptotic significances. The significance level was 0.05

${ }^{1}$ Each cell indicates the mean sample position for the variable item 
Table 19 Correlation test-item 9 (all courses)

\begin{tabular}{|c|c|c|c|c|c|c|c|c|c|}
\hline & & & 11 & 14 & 15 & 16 & 17 & 111 & 114 \\
\hline \multirow[t]{3}{*}{ Spearman's rho } & Item 9 & Correlation coefficient & 0.033 & $0.173^{* *}$ & $0.146^{*}$ & $0.131^{*}$ & $0.488^{* *}$ & $0.404^{* *}$ & $0.491^{* *}$ \\
\hline & & Sig. (two-tailed) & 0.618 & 0.008 & 0.026 & 0.047 & 0.000 & 0.000 & 0.000 \\
\hline & & $N$ & 231 & 231 & 231 & 231 & 231 & 231 & 231 \\
\hline
\end{tabular}

*Significant correlation at 0.05 (two-tailed)

**Significant correlation at 0.01 (two-tailed)

provide some evidence for the influence of requirements regarding knowledge of mathematics and algorithmic abstraction on the dropout of students from Computing degree courses. It should be emphasized that the survey of circumvented students was performed in a public institution (UnB). Thus, the reasons for dropout are slightly different than for private institutions. For instance, it is reasonable that socioeconomic issues would have a higher impact on dropout in private institutions than in public ones. It can also be observed that students associate their difficulties in mathematics- and algorithm-related subjects with institutional factors such as classes taught by professors and evaluation criteria. Thus, the evidence points to a need for investment in teacher training.

An understanding of dropout from Computing degree courses has a great importance in the search for subsidies to mitigate this problem. Education managers can benefit from such information. In the face of the reasons highlighted in the present study, which mainly focus on institutional and vocational issues, measures can be suggested to decrease dropout rates from Computing degree courses: motivating students to form study groups with periodic meetings; stimulation of monitoring works with granting of benefits; teaching of reinforcement classes early in the course for students experiencing difficulties in algorithm-based and calculation subjects; with the aid of psychology professionals, students could be monitored in order to check their affinity with the course, since students often begin a degree course full of uncertainty, and professional guidance can help them to change courses (if applicable) within the same institution; encouraging students to participate as collaborators in scientific and extension projects, where possible associating theory and practice, and encouraging students to work in a team, which is an essential requirement in the job market.

Table 20 Percentage of answers according to classification

\begin{tabular}{llll}
\hline Classification of issues & \multicolumn{3}{l}{ Course } \\
\cline { 2 - 4 } & $\begin{array}{l}\text { Computer } \\
\text { Science }\end{array}$ & $\begin{array}{l}\text { Computer } \\
\text { Engineering }\end{array}$ & $\begin{array}{l}\text { Degree in } \\
\text { Computing }\end{array}$ \\
\hline Vocational issues & 7.69 & 0.00 & 3.70 \\
Socioeconomic issues & 0.00 & 5.00 & 14.81 \\
Family/personal/health issues & 7.69 & 5.00 & 14.81 \\
Institutional issues & 42.31 & 60.00 & 62.96 \\
Other issues & 42.31 & 30.00 & 14.81 \\
\hline
\end{tabular}

Although difficulties in mathematics-related subjects and in algorithmic abstraction are not the only reasons for dropout from computing courses and are associated with other reasons, their relevance was observed in terms of dropout. An understanding of these difficulties within computing courses can contribute towards a decrease in dropout rates.

\section{Abbreviations}

CSV: Comma-separated values; ASCll: American Standard Code for Information Interchange; ENEM: National secondary education examination. The ENEM is a non-compulsory, standardized Brazilian national exam, managed by the Ministry of Education's National Institute for Educational Studies and Research (INEP). The ENEM is used as an admission exam for enrollment in many public and private universities in Brazil; INEP: National Institute for Educational Studies and Research "Anísio Teixeira"; OECD: Organisation for Economic Co-operation and Development; PAS: Program of Serial Evaluation. PAS is a form of entrance into higher education in Brazil adopted by several universities, divided into three exams done at the end of each year of high school; SBC: Brazilian Computer Society; SISU: The Unified Selection System is a federal government program that uses students' ENEM scores to classify candidates for openings in public universities without taking the Vestibular; UnB: University of Brasilia

\section{Acknowledgements}

We thank the Secretariat of Academic Records at UnB, which kindly and rapidly provided student records, thus enabling them to be contacted for the present study.

Availability of data and materials

The data from INEP can be downloaded from http://portal.inep.gov.br/microdados.

Authors' contributions

All authors have contributed equally to this work in terms of data sampling, writing, and reading. All authors read and approved the final manuscript.

Ethics approval and consent to participate

Not applicable.

Consent for publication

Not applicable.

\section{Competing interests}

The authors declare that they have no competing interests.

\section{Publisher's Note}

Springer Nature remains neutral with regard to jurisdictional claims in published maps and institutional affiliations.

\section{Author details}

${ }^{1}$ Federal Institute of Education, Science and Technology of Northern Minas Gerais (IFNMG), Farm São Geraldo, Kilometer 06, Januária, MG CEP 39480-000, Brazil. ${ }^{2}$ Department of Computer Science, University of Brasilia (UnB), CP 4466, Brasilia, DF CEP 70919-970, Brazil. 
Received: 13 June 2017 Accepted: 20 July 2018

Published online: 09 August 2018

\section{References}

1. Abu-Oda GS, El-Halees AM (2015) Data mining in higher education: university student dropout case study. Int J Data Min Knowl Manage Proc 5:15-27

2. Barcelos TS, Silveira IF (2012) Pensamento computacional e educação matemática: relações para o ensino de computação na educação básica. In: XX Workshop sobre Educação em Computação, Curitiba. Anais do XXXII Congresso da Sociedade Brasileira de Computação, Mackenzie Presbyterian University, Curitiba, pp 16-19

3. Barroso MF, Falcão EB (2004) Evasão universitária: o caso do Instituto de Física da UFRJ. In: Anais do $9^{\circ}$ encontro nacional de pesquisa em ensino de física. Federal University of Rio de Janeiro, Jaboticatubas, pp 26-30

4. Brasil (2016) SESu/MEC. Diplomação, Retenção e Evasão nos Cursos de Graduação em Instituições de Ensino Superior Públicas. http://www.andifes. org.br/wp-content/files_flutter/Diplomacao_Retencao_Evasao_Graduacao_ em_IES_Publicas-1996.pdf. Accessed 22 May 2017.

5. Dancey C, Reidy J (2006) Estatística sem matemática para psicologia: usando SPSS para Windows. Artmed, Porto Alegre

6. Gaioso NPL (2005) Evasão discente na educação superior: a perspectiva dos dirigentes e dos alunos. Dissertação, Universidade Católica de Brasília.

7. Godoy AS (1995) Introdução à pesquisa qualitativa e suas possibilidades. Rev Adm Empres 35:57-63

8. Gruner S (2015) On the future of computer science in South Africa: a survey amongst students at university. In: Proceedings of the 44th annual Southern African Computer Lecturers Association, University of the Witwatersrand, Johannesburg, 1-3 July 2015.

9. Hair JF Jr, Black WC, Babin BJ, Anderson RE, Tatham RL (2005) Multivariate data analysis. Prentice Hall, New Jersey

10. Hora HRM, Monteiro GTR, Arica J (2010) Confiabilidade em questionários para qualidade: um estudo com o coeficiente alfa de Cronbach. Produto Produção 11:85-103

11. INEP (Instituto Nacional de Estudos e Pesquisas Educacionais Anísio Teixeira) (2012). Resumo técnico censo da educação superior de 2010. http:// download.inep.gov.br/download/superior/censo/2010/resumo_tecnico_ censo_educacao_superior_2010.pdf. Accessed 02 Jan 2017.

12. Kinnunen P, Malmi L (2006) Why students drop out CS1 course? In: Proceedings of the 2nd International Workshop on Computing Education Research, Canterbury, United Kingdom, 9-10 September 2006

13. Maroco J (2014) Análise estatística com o SPSS Statistics. Report Number, Pêro Pinheiro.

14. Maroco J, Garcia-Marques T (2013) Qual a fiabilidade do alfa de Cronbach? Questões antigas e soluções modernas? Laboratório de Psicologia 4:65-90

15. Nunes DJ (2008) Estatísticas da educação superior: área da computação. Relatório Técnico, Sociedade Brasileira de Computação

16. OCDE (Organização para a Cooperação e Desenvolvimento Econômico) (2016) Classificação internacional EUROSTAT/UNESCO/OCDE. http:// download.inep.gov.br/download/superior/2009/Tabela.OCDE.2009.pdf. Accessed 3 Mar 2016.

17. Paula LQD, Piva D Jr, Freitas RL (2009) A leitura e a abstração do problema no processo de formação do raciocínio lógico-abstrato em alunos de computação. Reverte 1:124-133

18. Piva D Jr, Freitas RL (2011) Estratégias para melhorar os processos de abstração na disciplina de algoritmos. In: Anais of the Simpósio Brasileiro de Informática na Educação of the 31st Congresso da Sociedade Brasileira de Computação, Federal University of Pernambuco, Pernambuco, 23-26 November 2010

19. Silva Filho RLL, Motejunas PR, Hipólito O, Lobo MBCM (2007) A evasão no ensino superior brasileiro. Cad Pesqui 37:641-659

20. Souza C, Petró C, Gessinger R (2012) Um estudo sobre evasão no ensino superior do Brasil nos últimos dez anos: as possíveis causas e fatores que influenciam no abandono. Prevendo o risco do abandono. In: Anais of the 2nd Conferência Latinoamericana Sobre el Abandono em la Educacion Superior, Pontifical Catholic University of Rio Grande do Sul Porto Alegre, 8-9 November 2012

21. Vieira S (2003) Bioestatística - tópicos avançados. Editora Campus, Rio de Janeiro

22. Xenos M, Pierrakeas C, Pintelas P (2002) A survey on student dropout rates and dropout causes concerning the students in the course of informatics of the Hellenic Open University. Comput Educ 39:361-377

\section{Submit your manuscript to a SpringerOpen ${ }^{\circ}$ journal and benefit from:}

- Convenient online submission

- Rigorous peer review

- Open access: articles freely available online

High visibility within the field

- Retaining the copyright to your article

Submit your next manuscript at $\boldsymbol{\nabla}$ springeropen.com 